Article

\title{
Active Antioxidant Phenolics from Brazilian Red Propolis: An Optimization Study for Their Recovery and Identification by LC-ESI-QTOF-MS/MS
}

\author{
Daniel Vieira de Morais ${ }^{1}$, Pedro Luiz Rosalen ${ }^{2}$, Masaharu Ikegaki ${ }^{2}$, Anna Paula de Souza Silva ${ }^{3}$, \\ Adna Prado Massarioli ${ }^{3}$ and Severino Matias de Alencar $1,3, * \mathbb{E}$ \\ 1 Center for Nuclear Energy in Agriculture, University of São Paulo, Piracicaba, SP 13416-000, Brazil; \\ danielmorais@usp.br \\ 2 Faculty of Pharmaceutical Sciences, Federal University of Alfenas, Alfenas, MG 37130-001, Brazil; \\ pedro.rosalen@unifal-mg.edu.br (P.L.R.); masaharu.ikegaki@unifal-mg.edu.br (M.I.) \\ 3 Department of Agri-Food Industry, Food and Nutrition, 'Luiz de Queiroz' College of Agriculture, \\ University of São Paulo, Piracicaba, SP 13416-000, Brazil; anna.paula.silva@usp.br (A.P.d.S.S.); \\ adnaprado@usp.br (A.P.M.) \\ * Correspondence: smalencar@usp.br
}

\section{check for}

updates

Citation: Vieira de Morais, D.; Rosalen, P.L.; Ikegaki, M.;

de Souza Silva, A.P.; Massarioli, A.P.; de Alencar, S.M. Active Antioxidant Phenolics from Brazilian Red Propolis: An Optimization Study for Their Recovery and Identification by LC-ESI-QTOF-MS/MS. Antioxidants 2021, 10, 297. https://doi.org/ 10.3390/antiox10020297

Academic Editor: Miguel Vilas-Boas

Received: 24 December 2020

Accepted: 8 February 2021

Published: 16 February 2021

Publisher's Note: MDPI stays neutral with regard to jurisdictional claims in published maps and institutional affiliations.

Copyright: (c) 2021 by the authors. Licensee MDPI, Basel, Switzerland. This article is an open access article distributed under the terms and conditions of the Creative Commons Attribution (CC BY) license (https:/ / creativecommons.org/licenses/by/ $4.0 /)$.
Abstract: Brazilian red propolis (BRP) is a natural product widely known for its phenolic composition and strong antioxidant properties. In this study, we used the Box-Behnken Design (BBD) with Surface Response Methodology to optimize the extraction conditions for total phenolic content (TPC) and Trolox equivalent antioxidant capacity(TEAC) of bioactive phenolics from BRP. The extraction time, ethanol/water concentration and temperature, were tested. All variables had significant effects $(p \leq 0.05)$, with a desirability coefficient of 0.88 . Under optimized conditions $(90 \%$ ethanol at $80{ }^{\circ} \mathrm{C}$ for $30 \mathrm{~min}$ ), the BRP extract showed a TPC of $129.00 \pm 2.16 \mathrm{mg}$ GAE/g and a TEAC of $3471.76 \pm 53.86 \mu \mathrm{mol}$ TE/g. Moreover, FRAP and ORAC assays revealed that the optimized BRP extract had $1472.86 \pm 72.37 \mu \mathrm{mol} \mathrm{Fe}{ }^{2+} / \mathrm{g}$ and $4339.61 \pm 114.65 \mu \mathrm{mol} \mathrm{TE} /$ gof dry weight, respectively. Thirty-two phenolic compounds were tentatively identified by LC-QTOF-ESI-MS/MS, of which thirteen were found for the first time in BRP, including four flavones, one flavanol, two flavanones, two chalcones, and four isoflavonoids. Thus, our results highlight the importance of BRP as a source of a wide variety of phenolic compounds with significant antioxidant properties.

Keywords: isoflavonoids; bioactive compounds; Box-Behnkendesign; natural products; Apis mellifera

\section{Introduction}

Propolis or bee glue is a resinous balsamic substance collected by bees from plant exudates. It is naturally used to protect the hive and as an efficient antiseptic [1,2]. Historically, propolis has been used as a therapeutic substance in folk medicine, but recent advances in science and technology are increasing its commercial value in the food and pharmaceutical industries [3].

Among the different types of propolis occurring worldwide, Brazilian red propolis (BRP) stands out for its health benefits, which are attributed to a phenolic-rich composition, mainly isoflavonoids. The mechanisms of action of some BRP compounds, such as formononetin, vestitol, and neovestivol, were recently examined. These constituents were found to have strong antioxidant, anti-inflammatory, and antimicrobial properties $[4,5]$.

To date, more than 200 compounds have been identified in BRP [4,6-9], most of which are polyphenols. Propolis composition is causally related to both its botanical source and environmental conditions. The main botanical sources of BRP are Dalbergia ecastaphyllum, a rich source of isoflavonoids, and Symphonia globulifera, a rich source of polyprenylated benzophenones (guttiferone E and oblongifolin B) and triterpenoids ( $\beta$-amyrin and glutinol) [9]. 
Although several studies have correlated the presence of phenolics with the biological activity of BRP, mainly antimicrobial, antioxidant, anti-inflammatory, and anti-cancer properties [10-12], an optimization of extraction conditions has not been carried out thus far. The chemical extraction is the initial procedure for recovery of polyphenols from a natural product. Thus, choosing appropriate extraction conditions (e.g., sample-tosolvent ratio, solvent concentration, temperature, and extraction time) is utterly important as these may affect the final extract composition and bioactivity [13].

As stated by Riswanto et al. [14], the Response Surface Methodology (RSM) is a technique widely applied in the optimization of natural products due to its advantages compared to the traditional one-variable-at-a-time design. When combined with an experimental design like the Box-Behnken Design (BBD), it can be employed as a mathematical and statistical tool in natural product research. Due to its capacity of reducing the number of experiments required to find optimal conditions, BBD has been effectively used to optimize polyphenol extraction $[13,15]$.

Several studies have reported the phenolic composition of BRP, but none of them were carried out under optimized extraction conditions. In addition, the few studies addressing atentative identification of phenolicsby High-Resolution Mass Spectrometrywere not carried out in negative mode.Here, the optimization procedureallowedus toidentifyseveral unknownphenolic compounds in the BRP extract.

Our study hypothesis was that the optimized BRP extract had a greater number of phenolic compounds - many of which yet unknown — and stronger antioxidant activity.

Therefore, the aim of this study was to establish the optimal extraction conditions for the recovery of antioxidant compounds from BRP and to evaluate the new phenolic composition of the optimized extracts by LC-ESI-QTOF-MS/MS in negative mode.

\section{Materials and Methods}

\subsection{Chemicals}

The following chemicals were used in this study: Folin-Ciocalteau reagent (DinamicaQuimicaContemporanea, Diadema, SP, Brazil); sodium carbonate, potassium chloride, ethanol $(\mathrm{EtOH}) ;$ monobasic and dibasic potassium phosphate. The standards $(\{ \pm\})-6-$ hydroxy-2,5,7,8-tetramethylchromane-2-carboxylic acid (Trolox), gallic acid, diammonium salt (ABTS) and potassium peroxydisulfate, fluorescein sodium salt and 2,20-azobis(2methylpropionamidine) dihydrochloride (AAPH) were purchased from Sigma-Aldrich (St. Louis, MO, USA). All other reagents and solvents were of analytical grade.

\subsection{Propolis Collection and Extraction}

BRP samples were collected from the internal parts of Apis mellifera L. (Apidae) beehives located in the city of Maceió $\left(9^{\circ} 40^{\prime} \mathrm{S}, 35^{\circ} 41^{\prime} \mathrm{W}\right)$, Alagoas State, Northeastern Brazil. Access to the Brazilian genetic heritage was previously obtained in accordance with the Brazilian legislation SECEX/CGEN Ordinance No. 1. Approval for sample collection was obtained via the SISGEN platform under accession number A5A0509.

Propolis samples were crushed with liquid nitrogen, weighted $(0.5 \mathrm{~g})$, mixed with $50 \mathrm{~mL}$ of solvent and remained in sealed tubes in a bath shaker (Gyromax 929, Amerex) for the time and temperature established in the experimental design (Table 1). After that, $\mathrm{BRP}$ ethanolic extracts were kept overnight at $-20^{\circ} \mathrm{C}$ until complete wax decantation. The supernatant solution was filtered, concentrated on a rotary evaporator at $110 \mathrm{mbar}$ and $50{ }^{\circ} \mathrm{C}$, lyophilized, and then used in the analysis of antioxidant activity and total phenolic content. All extraction procedures were carried out in triplicate. 
Table 1. Box-Behnken Design for the extraction of antioxidants compounds from Brazilian red propolis extracts.

\begin{tabular}{|c|c|c|c|c|c|c|c|c|}
\hline \multirow[t]{3}{*}{ Run } & \multicolumn{5}{|c|}{ Independent Variables } & \multicolumn{3}{|c|}{ Dependent Variables } \\
\hline & \multicolumn{3}{|c|}{ Coded Values } & \multicolumn{3}{|c|}{ Real Values } & \multirow{2}{*}{$\begin{array}{c}\text { TEAC } \\
(\mu \mathrm{mol} \mathrm{TE} / \mathrm{g})\end{array}$} & \multirow{2}{*}{$\begin{array}{c}\text { TPC } \\
\text { (mg GAE/g) }\end{array}$} \\
\hline & Time (min) & Temp. ${ }^{\circ} \mathrm{C}$ & EtOH (\%) & Time (min) & Temp. ${ }^{\circ} \mathrm{C}$ & EtOH (\%) & & \\
\hline 1 & -1 & -1 & 0 & 30 & 30 & 75 & 2560.36 & 125.76 \\
\hline 2 & 1 & -1 & 0 & 90 & 30 & 75 & 2386.42 & 132.80 \\
\hline 3 & -1 & 1 & 0 & 30 & 80 & 75 & 2804.74 & 136.17 \\
\hline 4 & 1 & 1 & 0 & 90 & 80 & 75 & 2918.30 & 118.82 \\
\hline 5 & -1 & 0 & -1 & 30 & 55 & 60 & 2370.61 & 120.30 \\
\hline 6 & 1 & 0 & -1 & 90 & 55 & 60 & 2719.93 & 116.09 \\
\hline 7 & -1 & 0 & 1 & 30 & 55 & 90 & 3106.62 & 127.64 \\
\hline 8 & 1 & 0 & 1 & 90 & 55 & 90 & 3156.93 & 123.38 \\
\hline 9 & 0 & -1 & -1 & 60 & 30 & 60 & 3169.87 & 118.82 \\
\hline 10 & 0 & 1 & -1 & 60 & 80 & 60 & 2827.74 & 116.53 \\
\hline 11 & 0 & -1 & 1 & 60 & 30 & 90 & 3200.06 & 109.49 \\
\hline 12 & 0 & 1 & 1 & 60 & 80 & 90 & 3471.75 & 126.25 \\
\hline 13 & 0 & 0 & 0 & 60 & 55 & 75 & 2544.55 & 133.00 \\
\hline 14 & 0 & 0 & 0 & 60 & 55 & 75 & 2635.12 & 137.06 \\
\hline 15 & 0 & 0 & 0 & 60 & 55 & 75 & 2622.18 & 134.98 \\
\hline
\end{tabular}

Temp. = Temperature; EtOH = Ethanol; TEAC= Trolox equivalent antioxidant capacity; $\mathrm{TPC}=$ Total phenolic compounds.

\subsection{Experimental Deisgn and Optimization}

The following independent variables were considered: Time (X1) (30-90 min), temperature $(\mathrm{X} 2)\left(30-80^{\circ} \mathrm{C}\right)$, and percentage of ethanol/water $(\mathrm{X} 3)(60-90 \%, v / v)$. Following the Box-Behnken design, 15 experiments with 3 central points were performed to determine the effects of these independent parameters on two dependent responses (TEAC and TPC) (Table 1). RSM was performed to investigate the relationship between the independent and dependent variables. The quadratic polynomial model is represented by the following equation:

$$
Y=b_{0}+\sum_{i=1}^{3} b_{i} X_{i}+\sum_{i=1}^{3} b_{i i} X_{i j}+\sum_{i<1}^{3} b_{i j} X_{i} X_{j}
$$

where, $Y$ is the dependent variable (antioxidant activity) for the independent responses $\left(X_{1}-X_{3}\right)$; and $\beta_{0}, \beta_{i}, \beta_{i i}$, and $\beta_{i j}$ are constant coefficients of intercept, linear, quadratic, and interaction terms.

\subsection{Total Phenolic Content}

The analysis of total phenolic content (TPC) was performed according to the FolinCiocalteau spectrophotometric method, with some modifications. Aliquots of $20 \mu \mathrm{L}$ of the standard solution (gallic acid) or BRP extract and $100 \mu \mathrm{L}$ of the Folin-Ciocalteau solution ( $10 \%$ in water) were pipetted into the wells of a microplate. After $5 \mathrm{~min}, 75 \mu \mathrm{L}$ of a $7.5 \%$ sodium carbonate aqueous solution were added to each well. A control was prepared by replacing the sample with distilled water. The absorbance was measured at $740 \mathrm{~nm}$ in a microplate reader (Molecular Devices, LLC, Sunnyvale, CA, USA) after $40 \mathrm{~min}$. The TPC was calculated by linear regression using gallic acid as a standard, and the results were expressed as mg of gallic acid equivalents (GAE) per g of dry extract [16]. All samples were analyzed in triplicate.

\subsection{Antioxidant Activity}

\subsubsection{Ferric Reducing Antioxidant Power (FRAP) Assay}

Briefly, $20 \mu \mathrm{L}$ of BRP extract were mixed with $30 \mathrm{~mL}$ of water and $200 \mu \mathrm{L}$ of FRAP reagent (prepared fresh daily) in a 96-well microplate. The FRAP reagent consisted of 10 volumes of $300 \mathrm{mmol} / \mathrm{L}$ acetate buffer ( $\mathrm{pH} 3.6$ ), one volume of $20 \mathrm{mmol} / \mathrm{L} \mathrm{FeCl}_{3}$, and 
one volume of $10 \mathrm{mmol} / \mathrm{L} \mathrm{TPTZ} \mathrm{in} 40 \mathrm{mmol} / \mathrm{L} \mathrm{HCl} \mathrm{[16].} \mathrm{The} \mathrm{absorbance} \mathrm{was} \mathrm{measured}$ at $595 \mathrm{~nm}$ in a microplate reader (Molecular Devices, LLC, Sunnyvale, CA, USA) after $8 \mathrm{~min}$. Water was used as a blank; ferrous sulphate solutions (100 to $700 \mu \mathrm{M})$ were used for calibration; and the FRAP value was calculated by linear regression. The assay was performed in triplicate, and the results were estimated as $\mu \mathrm{mol} \mathrm{Fe}{ }^{2+} / \mathrm{g}$ of dry extract.

\subsubsection{Peroxyl Radical (ROO $\bullet$}

Briefly, $30 \mu \mathrm{L}$ of BRP extract plus $60 \mu \mathrm{L}$ of fluorescein and $110 \mu \mathrm{L}$ of an AAPH solution were transferred to a microplate. The reaction was performed at $37^{\circ} \mathrm{C}$ and the absorbance was measured every minute for $2 \mathrm{~h}$ at $485 \mathrm{~nm}$ (excitation) and $528 \mathrm{~nm}$ (emission) in a microplate reader (Molecular Devices, LLC, Sunnyvale, CA, USA). Trolox standard was used at concentrations ranging from 12.5 to $400 \mu \mathrm{M}$. The results were expressed as $\mu \mathrm{mol} /$ Trolox equivalents (TE) per $\mathrm{g}$ of dry extract [17]. The assay was carried out in triplicate.

\subsubsection{Trolox Equivalent Antioxidant Capacity (TEAC) Assay}

The antioxidant capacity of the BRP extract was determined based on free radical ABTS, with modifications [16]. The ABTS radical was diluted in $75 \mathrm{mM}$ potassium phosphate buffer (Ph 7.4) to an absorbance of $0.700 \pm 0.01$ at $734 \mathrm{~nm}$. Aliquots of $20 \mu \mathrm{L}$ of Trolox or BRP extract and $220 \mu \mathrm{L}$ of ABTS radical solution were transferred to the wells and kept at room temperature protected from light. After $6 \mathrm{~min}$ of reaction, the absorbance was read at $734 \mathrm{~nm}$ using the potassium phosphate buffer as a blank. Trolox was used as a standard at concentrations ranging from 12.5 to $200 \mu \mathrm{M}$, and the results were expressed as $\mu \mathrm{mol}$ Trolox equivalents (TE) per $g$ of dry extract.

\subsection{High-Resolution Mass Spectrometry Analysis (LC-ESI-QTOF-MS/MS)}

Liquid chromatography analysis was carried out in a chromatograph (Shimadzu Co., Tokyo) with a LC-30AD quaternary pump and SPD-20A photodiode array detector (PDA). Reversed phase chromatography was performed using a Phenomenex Luna C18 column $(4.6 \times 250 \mathrm{~mm} \times 5 \mu \mathrm{M})$. A high-resolution mass spectrometer (MAXIS 3G-Bruker Daltonics, Bremen, Germany) was equipped with a Z-electrospray (ESI) interface operating in negative ion mode with a nominal resolution of $60,000 \mathrm{~m} / \mathrm{z}$. Twenty microliters of the BRP extract were injected into the liquid chromatography system. The analytical conditions were set as follows: Nebulizer at 2 Bar; dry gas at $8 \mathrm{~L} / \mathrm{min}$; temperature at $200{ }^{\circ} \mathrm{C}$ and $\mathrm{HV}$ at $4500 \mathrm{~V}$. The mobile phase consisted of two solvents: (A) Water/acetic acid $(99.5 / 0.5, v / v)$ and (B) methanol. The flow rate was $1 \mathrm{~mL} / \mathrm{min}$, and the gradient was initiated with $30 \% \mathrm{~B}$, increasing to $40 \% \mathrm{~B}(15 \mathrm{~min}), 50 \% \mathrm{~B}(30 \mathrm{~min}), 60 \% \mathrm{~B}(45 \mathrm{~min}), 75 \% \mathrm{~B}(65 \mathrm{~min})$, 75\% B (85 min), 90\% B (95 min), decreasing to 30\% B (105 min). The run was complete after $114 \mathrm{~min}$. An external calibration was carried out in MAXIS 3G-Bruker Daltonics 4.3 software to check for mass precision and data analysis. The tentative identification of the compounds was performed by comparing their exact mass $(m / z)$ and $\mathrm{MS}^{2}$ spectra in negative mode to the database available in the literature and commercial standards (naringenin, pinocembrin, isoliquiritigenin, daidzein, formononetin andbiochanin A) from Sigma-Aldrich (St. Louis, MO, USA).

\subsection{Data Analysis}

STATISTICA 7.0 software was used to analyze the multivariate factorial design (ANOVA) and to determine the significance of the variables. The accuracy of the mathematical models was estimated by the coefficient of determination $\left(\mathrm{R}^{2}\right)$ and the F-test $(p<0.05)$. All assays were carried out in triplicate, and the values were expressed as mean \pm standard deviation. 


\section{Results and Discussion}

\subsection{Fitting the Models to Data}

In this study, ANOVA was used to evaluate the accuracy of the RSM models (Table 2). The $p$-values $(p<0.05)$ observed for both response variables were considered significant, indicating that the developed models are appropriate to represent the relationship between the independent parameters and the response variables.

Table 2. The effects of different parameters on Trolox equivalent antioxidant capacity (TEAC) and total phenolic content (TPC) outcomes during optimization of Brazilian red propolis ethanolic extracts.

\begin{tabular}{|c|c|c|c|c|c|c|}
\hline Term & SS & df & MS & F-Value & $p$-Value & Remarks \\
\hline \multicolumn{7}{|l|}{ TEAC } \\
\hline Model & $1,247,423.00$ & 9 & $138,602.55$ & 603.14 & $<0.0001$ & significant \\
\hline$X_{1}$ & 8019.54 & 1 & 8019.54 & 34.89 & 0.0183 & \\
\hline$x_{2}$ & $74,849.67$ & 1 & $74,849.67$ & 325.63 & 0.0020 & \\
\hline$x_{3}$ & 425,485 & 1 & $425,484.7$ & 1851.06 & 0.0003 & \\
\hline$X_{1}^{2}$ & 83.58 & 1 & 83.58 & 0.3636 & 0.5347 & \\
\hline$X_{2}^{\frac{1}{2}}$ & 144,174 & 1 & $144,173.8$ & 627.22 & 0.0010 & \\
\hline$X_{3}^{2}$ & 530,460 & 1 & $530,460.1$ & 2307.80 & 0.0002 & \\
\hline $\mathrm{X}_{1} \mathrm{X}_{2}$ & 1153.35 & 1 & 1153.35 & 5.02 & 0.1092 & \\
\hline$x_{1} x_{3}$ & 1.87 & 1 & 1.87 & 0.0081 & 0.9254 & \\
\hline$x_{2} x_{3}$ & $94,179.02$ & 1 & $94,179.02$ & 409.73 & 0.0016 & \\
\hline Residual & 1149.29 & 5 & 229.86 & & & \\
\hline Lack of Fit & 846.99 & 3 & 282.33 & 1.87 & 0.3673 & non-significant \\
\hline Pure error & 302.30 & 2 & 151.15 & & & \\
\hline Total & $1,248,572$ & 14 & & & & \\
\hline$R^{2}$ & 0.9991 & & & & & \\
\hline $\begin{array}{c}\text { Adj-R }{ }^{2} \\
\text { TPC }\end{array}$ & 0.9974 & & & & & \\
\hline Model & 627.04 & 9 & 69.67 & 34.75 & 0.0006 & significant \\
\hline$X_{1}$ & 134.88 & 1 & 134.88 & 67.27 & 0.0004 & \\
\hline$x_{2}$ & 10.38 & 1 & 10.38 & 5.18 & 0.0719 & \\
\hline$x_{3}$ & 9.45 & 1 & 9.45 & 4.71 & 0.0820 & \\
\hline $\mathrm{X}_{1}^{2}$ & 39.29 & 1 & 39.29 & 19.60 & 0.0068 & \\
\hline$X_{2}^{\frac{1}{2}}$ & 250.65 & 1 & 250.65 & 125.01 & $<0.0001$ & \\
\hline$X_{3}^{2}$ & 81.65 & 1 & 81.65 & 40.72 & 0.0014 & \\
\hline $\mathrm{X}_{1} \mathrm{X}_{2}$ & 5.97 & 1 & 5.97 & 2.98 & 0.1449 & \\
\hline$x_{1} x_{3}$ & 1.10 & 1 & 1.10 & 0.5473 & 0.4927 & \\
\hline$x_{2} x_{3}$ & 132.72 & 1 & 132.72 & 66.20 & 0.0005 & \\
\hline Residual & 10.02 & 5 & 2.00 & & & \\
\hline Lack of Fit & 1.78 & 3 & 0.5938 & 0.1441 & 0.9251 & non-significant \\
\hline Pure error & 8.24 & 2 & 4.12 & & & \\
\hline Total & 637.07 & 14 & & & & \\
\hline $\mathrm{R}^{2}$ & 0.9843 & & & & & \\
\hline Adj- $R^{2}$ & 0.9559 & & & & & \\
\hline
\end{tabular}

$\mathrm{X}_{1}$ : Time $(\mathrm{min}), \mathrm{X}_{2}$ : Temperature $\left({ }^{\circ} \mathrm{C}\right), \mathrm{X}_{3}$ : EtOH (\%), SS: Sum of squares, DF: Degree of freedom, MS: Mean square, $\mathrm{R}^{2}$ : Quadratic correlation coefficient; Adj-R ${ }^{2}$ : Adjusted quadratic correlation coefficient. TEAC: Trolox equivalent antioxidant capacity; TPC: Total phenolic content.

Based on the statistical analysis, the F-values observed (603.14 and 34.75 for TEAC and TPC, respectively) were significant and the model fitted well, as the $p$-value was lower than 0.05 . The $p$-value is used to estimate whether $\mathrm{F}$ is large enough to indicate statistical significance, and values lower than 0.05 for this parameter indicate that the developed model is statistically significant [18]. Hence, the independent variables affected the TEAC and TPC. The $p$-values for Lack of Fit in both models were greater than 0.05 (0.3673 and 0.9251, TEAC and TPC respectively). This function is performed by comparing the variability of the residuals in the current model with the variability in the observations under repeated conditions of the factors [19]. The coefficient of determination $\left(R^{2}\right)$ estimates the proportion of variation in the response that can be attributed to the model rather than 
to random error [20]. In our study, the $\mathrm{R}^{2}$ values were 0.9991 and 0.9843 for TEAC and TPC, respectively, whereas the Adj- $R^{2}$ values were 0.9974 and 0.9559 for TEAC and TPC. High Adj- $R^{2}$ values are indicative of a high correlation between the observed and the predicted values [18]. Based on the estimated results, it is evident that the developed models have high adequacy and accuracy.

The contribution of coefficients for the response variable is presented in Table 2. It can be observed that the linear $\left(X_{1}, X_{2}\right.$ and $\left.X_{3}\right)$ and quadratic terms $\left(X_{2}^{2}\right.$ and $\left.X_{3}^{2}\right)$ and the interactive effects $\left(X_{2} X_{3}\right)$ affected the TEAC, while in TPC the highly significant terms were the linear $\left(X_{1}\right)$, quadratic $\left(X_{1}^{2}, X_{2}^{2}\right.$ and $\left.X_{3}^{2}\right)$ and interactive $\left(X_{2} X_{3}\right)$. The other coefficients were not significant $(p>0.05)$. Equations considering only the significant terms by RSM models were fitted to predict the responses, which are given below:

$$
\begin{gathered}
Y_{T E A C}=13117.53+3.05 X_{1}-60.23 X_{2}-259.73 X_{3}+0.31 X_{2}^{2}+1.68 X_{3}^{2}+0.41 X_{2} X_{3} \\
Y_{T P C}=135.01-4.11 X_{1}-60.23 X_{2}-3.26 X_{1}^{2}-8.24 X_{2}^{2}-4.70 X_{3}^{2}-0.52 X_{2} X_{3}
\end{gathered}
$$

where, $Y$ represents the predicting responses;and $X_{1}, X_{2}$ and $X_{3}$ represent time, temperature and $\%$ ethanol, respectively.

\subsection{Response Surface Analysis}

\subsubsection{The Effect of Solvent Concentration on TEAC and TPC}

As shown in Figures 1 and 2, solvent concentration significantly altered the content of bioactive compounds recovered from the BRP extract and its antioxidant activity. As the ethanol concentration increased, the efficiency of both phenolic extraction and antioxidant activity was greatly improved. TEAC values raised from 2700 to $3200 \mu \mathrm{mol} \mathrm{TE} / \mathrm{g}$ as the ethanol concentration was increased from $75 \%$ to $90 \%$. Similarly, TPC values raised from 123 to $135 \mathrm{mg} \mathrm{GAE} / \mathrm{g}$ as the ethanol concentration was increased from $60 \%$ to $90 \%$.

a

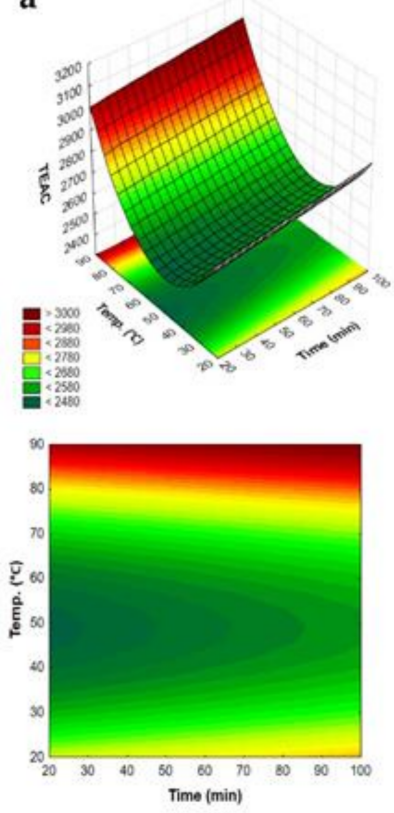

b
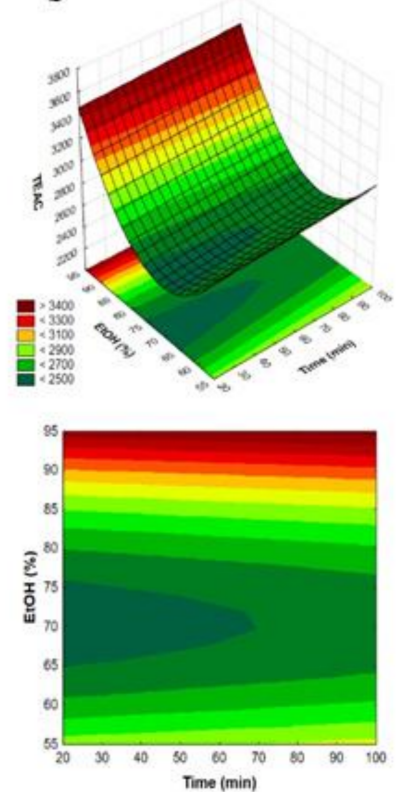

c
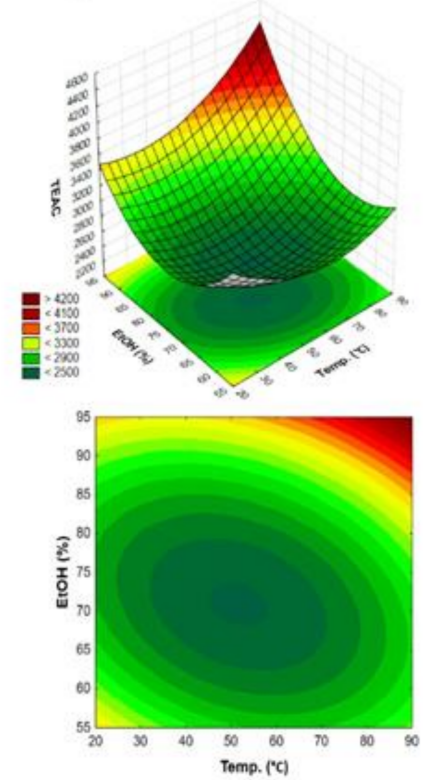

Figure 1. Response surface plot showing the combined effect of temperature $\left({ }^{\circ} \mathrm{C}\right)(\mathbf{a})$, time $(\mathrm{min})(\mathbf{b})$, and $\mathrm{EtOH}(\%)(\mathbf{c})$ on the TEAC of Brazilian red propolis extracts. 

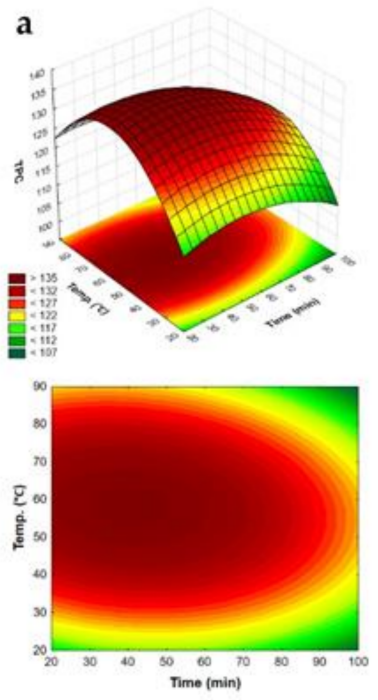
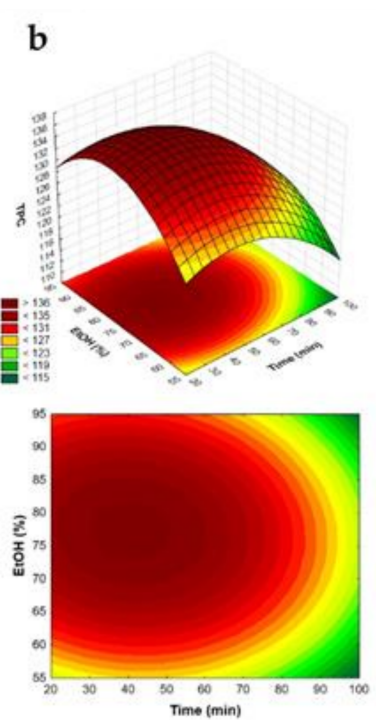

C

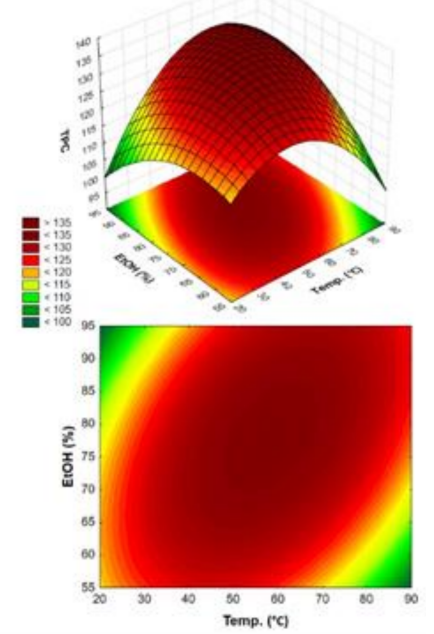

Figure 2. Response surface plot showing the combined effect of temperature $\left({ }^{\circ} \mathrm{C}\right)(\mathbf{a})$, time (min) $(\mathbf{b})$, and $\mathrm{EtOH}(\%)(\mathrm{c})$ on the TPC of Brazilian red propolis extracts.

Our data suggest that the interaction between temperature and ethanol concentration was highly significant. Hence, the phenolic content and TEAC values can be optimized if these parameters are increased. Yet, no improvement in phenolic extraction and antioxidant activity was observed at the highest ethanol concentration (90\%) and temperatures below $30^{\circ} \mathrm{C}$. A similar outcome was reported by Roselló-Soto et al. [21] during the optimization of Tiger Nuts byproducts. The authors showed that an increase in ethanol concentration significantly increased the extraction yield at temperatures above $40^{\circ} \mathrm{C}$. Oldoni et et al. [22] also reported that the optimized conditions for extraction of phenolic compounds with antioxidant activity from propolis were $80{ }^{\circ} \mathrm{C}$ and $70 \%$ ethanol. As proposed by Yang et al. [23], after modifying and penetrating through the cell wall, ethanol affects cell components and improves the chemical extraction, particularly of polyphenols.

Although it has not been extensively discussed in optimization studies, the extraction equipment plays a determining role in the efficiency of the optimization process. When experiments are carried out in non-sealed tubes, volatile solvents or nonpolar compounds may evaporate as rocking and sonification produce heat and increase the solvent temperature. Therefore, the use of an appropriate flask to perform the analysis is as important as the experimental design itself.

\subsubsection{The Effect of Temperature on TEAC and TPC}

Temperature is one of the variables most frequently examined in natural product optimization studies due to its effects on the content and availability of bioactive compounds, mainly polyphenols. In our study, we found that as the temperature increased so did the TEAC of the extract. The best results were obtained at the highest tested temperature $\left(80^{\circ} \mathrm{C}\right)$ $3471.75 \mu \mathrm{mol} \mathrm{TE} / \mathrm{g}$ (Figure 1). This value is higher than those found by Andrade et al. [24] when testing the extraction of red, green, and brown propolis at $35^{\circ} \mathrm{C}(2913.55 \pm 95.26$; $2214.96 \pm 20.61$ and $1868.45 \pm 131.39 \mu \mathrm{mol} \mathrm{TE} / \mathrm{g}$, respectively).

Moreover, the results showed that when the temperature was escalated from $30^{\circ} \mathrm{C}$ to $55^{\circ} \mathrm{C}$, the TPC increased from 122 to $128 \mathrm{mg} \mathrm{GAE} / \mathrm{g}$, but it decreased slightly when the temperature was further extended (Figure 2). Maran at al. [18] pointed out that higher temperatures enhance the efficiency of phenolic extraction by decreasing the viscosity and density of the extract. Thereby, higher temperatures enable the solvent to penetrate deeper into the sample matrix and have more contact with the surface area. However, if the temperature is excessively elevated, bioactive compounds may decompose or vaporize. 


\subsubsection{The Effect of Extraction Time on TEAC and TPC}

Figures 1 and 2 show the results of different extraction times on TEAC and TPC outcomes. Although this variable was not strongly associated with TEAC values, a shorter extraction time ( $30 \mathrm{~min}$ ) yielded better results. As for TPC, the optimal extraction time was also $30 \mathrm{~min}$. When the time was extended from 60 to $90 \mathrm{~min}$, the number of phenolic compounds recovered was drastically reduced. As stated in the literature, an extended extraction time increases the probability of oxidation, epimerization, and degradation of bioactive compounds [25]. Thus, a prolonged extraction procedure may not be appropriate for all types of natural products [21]. On the other hand, Oldoni et al. [22] reported an increase in the TPC of a propolis type produced in Southern Brazil when using $80 \%$ ethanol at $70{ }^{\circ} \mathrm{C}$ for $45 \mathrm{~min}$. Yusof et al. [26] observed that the optimal conditions for extraction of phenolics from a Malaysian propolis were $80 \%$ ethanol at $60^{\circ} \mathrm{C}$ for $25 \mathrm{~min}$. Importantly, we note that the optimal extraction time reported by these authors was shorter than that found in our study, and that it was not possible to predict the extraction efficiency after $60 \mathrm{~min}$.

\subsubsection{Optimization and Validation of RSM Models}

The optimization of the independent parameters-time ( $\mathrm{min})$, ethanol (\%) and temperature $\left({ }^{\circ} \mathrm{C}\right)$ - was carried out based on the desirability coefficient $(0.8780)$ to obtain the highest TEAC and TPC (See Supplementary Materials Figure S1). The TEAC and TPC values predicted by the model under optimal conditions $\left(90 \%\right.$ ethanol, $\left.80^{\circ} \mathrm{C}, 30 \mathrm{~min}\right)$ were $3550.8 \pm 70 \mu \mathrm{mol}$ TE/g and $132 \pm 6.48 \mathrm{mg}$ GAE/g, respectively. The RSM model was validated by comparing the experimental data $(n=3)$ with the predicted values. The actual TEAC and TPC values obtained under optimal conditions were $3471.76 \pm 53.86 \mu \mathrm{mol}$ TE/g and $129.00 \pm 2.16 \mathrm{mg} \mathrm{GAE} / \mathrm{g}$, respectively. These findings are similar to the predicted data, indicating that the method is suitable to determine the optimal conditions for extraction of phenolic compounds with antioxidant activity from BRP samples.

\subsection{Antioxidant Activity of the Optimized BRP Extract}

The antioxidant activity of the optimized BRP extract was evaluated in vitro by single electron transfer and hydrogen atom transfer assays. The FRAP method is based on the reduction of $\mathrm{Fe}^{3+}$ into $\mathrm{Fe}^{2+}$ by antioxidant compounds in the presence of 2,4,6-tris-(2pyridyl)-s-triazine (TPTZ), forming a colored complex with $\mathrm{Fe}^{2+}$ at $593 \mathrm{~nm}$ [27]. The FRAP value obtained for the optimized BRP extract was $1472.86 \pm 72.37 \mu \mathrm{mol} \mathrm{Fe}{ }^{2+} / \mathrm{g}$ of dry extract. These values were higher than those reported by Calegari et al. [27], who determined the antioxidant activity of 30 propolis samples collected in the states of Paraná and Santa Catarina, Brazil. The authors used Fourier transform near-infrared (FTNIR) spectroscopy and obtained FRAP values ranging from 61.9 to $1770 \mu \mathrm{mol} \mathrm{Fe} e^{2+} / \mathrm{g}$ of dry weight. Andrade et al. [24] reported a FRAP value of $633.18 \pm 40.20 \mu \mathrm{mol}$ TE/g of dry weight for the BRP extract, while Oldoni et al. [22] found $259.30 \pm 9.50 \mu \mathrm{mol} \mathrm{Fe}^{2+} / \mathrm{g}$ of dry weight for optimized propolis samples from the state of Paraná, Brazil. When evaluating Croatian propolis from five locations in Adriatic Sea islands, Sveĉnjak et al. [28] observed reducing FRAP activity from 0.1 to $0.8 \mathrm{mmol} \mathrm{Fe}{ }^{2+} / \mathrm{g}$ of dry weight.

The oxygen radical absorbance capacity (ORAC) assay measures antioxidant inhibition of the peroxyl radical via hydrogen atom transfer reactions. This method is suitable to detect both hydrophilic and hydrophobic antioxidants [29]. For that reason, it is commonly used to determine the antioxidant capacity of different types of natural products, including propolis. In our study, the ORAC value of the BRP extract was $4339.61 \pm 114.65 \mu \mathrm{mol}$ TE/gof dry extract. El-Guendouz et al. [30] examined 24 different samples of Moroccan propolis and found ORAC values ranging from $630.39 \pm 33.79$ to $1723.28 \pm 33.79 \mu \mathrm{mol} \mathrm{TE} / \mathrm{g}$ of dry weight. Using 95\% ethanol for extraction, Sun et al. [31] reported that Beijing propolis extract had an ORAC value of $1433.72 \pm 120 \mu \mathrm{mol}$ TE/g of dry weight. Finally, a high correlation between the phenolic composition and antioxidant activity of the optimized extract was observed in our study (ABTS, $\mathrm{r}^{2}=0.9925 ; \mathrm{FRAP}=-0.7321$ and $\mathrm{ORAC}=0.8152$ ). 


\subsection{Characterization of Phenolic Compounds in the Optimized BRPExtract by LC-ESI-QTOF-MS/MSAnalysis}

The qualitative analysis of the BRP extract composition was carried by LC-ESI-QTOFMS/MS. The compounds were tentatively identified by comparing their $m / z$ values and $\mathrm{MS}^{2}$ spectra in negative mode to the literature findings and corresponding standards.

As shown in Table 3, LC-MS/MS analysis revealed the presence of 32 phenolic compounds in the optimized BRP extract, including flavones, flavanones, flavanonols, chalcones, isoflavonoids, quinone, coumarin, and their derivatives.

Table 3. LC-ESI-QTOF-MS/MS analysis of phenolic compounds present in Brazilian red propolis.

\begin{tabular}{|c|c|c|c|c|c|}
\hline Compound & $\begin{array}{c}\text { Putative Compound } \\
\text { Name }\end{array}$ & RT (min) & ProposedFormula & {$[\mathbf{M}-\mathrm{H}]-(m / z)$} & MS/MS Fragments $(\mathrm{m} / z)$ \\
\hline \multicolumn{6}{|c|}{ Flavones } \\
\hline 1 & Chrysin & 28.6 & $\mathrm{C}_{15} \mathrm{H}_{10} \mathrm{O}_{4}$ & 253.0510 & $\begin{array}{c}\text { 253.0507; } 119.0483 ; \\
195.0438 ; 224.0481 ; \\
209.0614\end{array}$ \\
\hline 2 & Tricin & 34.2 & $\mathrm{C}_{17} \mathrm{H}_{14} \mathrm{O}_{7}$ & 329.0677 & $\begin{array}{l}\text { 329.0667; 299.0218; } \\
271.0263 ; 243.0289\end{array}$ \\
\hline 3 & Genkwanin & 36.2 & $\mathrm{C}_{16} \mathrm{H}_{12} \mathrm{O}_{5}$ & 283.0624 & $\begin{array}{c}268.0360 ; 283.0583 ; \\
269.0397\end{array}$ \\
\hline 4 & Hispidulin & 37.5 & $\mathrm{C}_{16} \mathrm{H}_{12} \mathrm{O}_{6}$ & 299.0565 & $\begin{array}{l}\text { 284.0331; 227.0354; } \\
255.0301 ; 212.0483\end{array}$ \\
\hline 5 & $\begin{array}{l}\text { 8-Hydroxy-5- } \\
\text { methoxyflavanone }\end{array}$ & 44.2 & $\mathrm{C}_{16} \mathrm{H}_{14} \mathrm{O}_{4}$ & 269.0831 & $\begin{array}{l}\text { 254.0589; 252.0437; } \\
195.0451 ; 210.0685\end{array}$ \\
\hline 6 & Acacetin & 54.2 & $\mathrm{C}_{16} \mathrm{H}_{12} \mathrm{O}_{5}$ & 283.0617 & $268.0382 ; 211.0408 ; 269.042$ \\
\hline \multicolumn{6}{|c|}{ Flavanones } \\
\hline 7 & Liquiritigenin & 25.1 & $\mathrm{C}_{15} \mathrm{H}_{12} \mathrm{O}_{4}$ & 255.0667 & $\begin{array}{l}119.0495 ; 135.0083 ; \\
255.0656 ; 120.0526\end{array}$ \\
\hline 8 & Naringenin * & 32.6 & $\mathrm{C}_{15} \mathrm{H}_{12} \mathrm{O}_{5}$ & 271.0619 & $\begin{array}{c}\text { 119.0487; } 151.0029 ; \\
254.0596 ; 271.0609 ; \\
165.0207\end{array}$ \\
\hline 9 & Pinocembrin * & 48.6 & $\mathrm{C}_{15} \mathrm{H}_{12} \mathrm{O}_{4}$ & 255.0668 & $\begin{array}{c}255.0678 ; 240.0426 \\
\text { 151.0034; } 133.0285 \\
213.0540\end{array}$ \\
\hline 10 & $\begin{array}{l}\text { 5,6-Dihydroxy-3' }{ }^{\prime} 4^{\prime}- \\
\text { dimethoxyflavanone }\end{array}$ & 48.7 & $\mathrm{C}_{17} \mathrm{H}_{16} \mathrm{O}_{6}$ & 315.0882 & $\begin{array}{c}\text { 315.0881;151.0037; } \\
\text { 235.0636; 255.1042; } \\
\text { 121.0292; }\end{array}$ \\
\hline 11 & 6-Hydroxyflavanone & 57.3 & $\mathrm{C}_{15} \mathrm{H}_{12} \mathrm{O}_{3}$ & 239.0722 & $\begin{array}{c}\text { 239.0732; } 135.0091 ; \\
197.0643\end{array}$ \\
\hline \multicolumn{6}{|c|}{ Chalcones } \\
\hline 12 & Isoliquiritigenin * & 41.1 & $\mathrm{C}_{15} \mathrm{H}_{12} \mathrm{O}_{4}$ & 255.0676 & $\begin{array}{c}\text { 119.0496; } 135.0082 ; \\
120.0531 ; 151.0384 ; \\
255.0665\end{array}$ \\
\hline 13 & $2^{\prime}, 4^{\prime}$-Dihydroxychalcone & 41.9 & $\mathrm{C}_{15} \mathrm{H}_{12} \mathrm{O}_{3}$ & 239.0723 & $\begin{array}{l}239.0709 ; 197.0609 ; \\
135.0085 ; 198.0667\end{array}$ \\
\hline 14 & 7-hydroxyflavanone & 42.2 & $\mathrm{C}_{15} \mathrm{H}_{12} \mathrm{O}_{3}$ & 239.0719 & $\begin{array}{l}\text { 197.0610; } 135.0085 ; \\
239.0732 ; 198.0643\end{array}$ \\
\hline 15 & $\begin{array}{c}2^{\prime}, 6^{\prime} \text {-dihydroxy- } 4^{\prime}- \\
\text { methoxydihydrochalcone }\end{array}$ & 45.2 & $\mathrm{C}_{16} \mathrm{H}_{16} \mathrm{O}_{4}$ & 271.0990 & $\begin{array}{c}\text { 254.0590; 135.0444; } \\
\text { 109.0287; }\end{array}$ \\
\hline
\end{tabular}


Table 3. Cont.

\begin{tabular}{|c|c|c|c|c|c|}
\hline Compound & $\begin{array}{l}\text { Putative Compound } \\
\text { Name }\end{array}$ & $\mathrm{RT}$ (min) & ProposedFormula & {$[\mathbf{M}-\mathbf{H}]-(m / z)$} & MS/MS Fragments $(\mathrm{m} / \mathrm{z})$ \\
\hline 16 & $\begin{array}{l}\text { 2'-Hydroxy-4'- } \\
\text { methoxychalcone }\end{array}$ & 49.9 & $\mathrm{C}_{16} \mathrm{H}_{14} \mathrm{O}_{3}$ & 253.0879 & $\begin{array}{c}237.0552 ; 255.0665 ; \\
253.0872 ; 136.0169 ; \\
161.0239\end{array}$ \\
\hline \multicolumn{6}{|c|}{ Isoflavonoids } \\
\hline 17 & Daidzein * & 28.7 & $\mathrm{C}_{15} \mathrm{H}_{10} \mathrm{O}_{4}$ & 253.0511 & $\begin{array}{l}\text { 253.0513; 208.0523; } \\
119.0488 ; 135.0089\end{array}$ \\
\hline 18 & Calycosin & 31.9 & $\mathrm{C}_{16} \mathrm{H}_{12} \mathrm{O}_{5}$ & 283.0617 & $\begin{array}{c}268.0353 ; 211.0422 ; \\
224.0506 ; 239.0313 \\
267.0665\end{array}$ \\
\hline 19 & Dihydrobiochanin A & 34.1 & $\mathrm{C}_{16} \mathrm{H}_{14} \mathrm{O}_{5}$ & 285.0776 & $\begin{array}{l}\text { 270.0541; 109.0289; } \\
161.0242 ; 285.0767\end{array}$ \\
\hline 20 & Vestitone & 34.5 & $\mathrm{C}_{16} \mathrm{H}_{14} \mathrm{O}_{5}$ & 285.0776 & $\begin{array}{l}\text { 270.0535; 161.0240; } \\
\text { 109.0286; 271.0607 }\end{array}$ \\
\hline 21 & Vestitol & 41.4 & $\mathrm{C}_{16} \mathrm{H}_{16} \mathrm{O}_{4}$ & 271.0987 & $\begin{array}{l}\text { 135.0450; 109.0282; } \\
\text { 149.0604; 147.0452; } \\
271.0986 ; 256.0747\end{array}$ \\
\hline 22 & Neovestitol & 41.8 & $\mathrm{C}_{16} \mathrm{H}_{16} \mathrm{O}_{4}$ & 271.0990 & $\begin{array}{c}\text { 135.0360; } \\
\text { 109.0217;256.0555; } \\
197.0482 ; 212.0707\end{array}$ \\
\hline 23 & Formononetin * & 43.9 & $\mathrm{C}_{16} \mathrm{H}_{12} \mathrm{O}_{4}$ & 267.0666 & $\begin{array}{c}252.0431 ; 254.0594 ; \\
223.0404 ; 195.0456 ; \\
253.0483\end{array}$ \\
\hline 24 & Demethyl medicarpin & 45.2 & $\mathrm{C}_{15} \mathrm{H}_{12} \mathrm{O}_{4}$ & 255.0673 & $\begin{array}{c}255.0668 ; 105.0189 \\
151.0032 ; 107.0118 \\
213.0532\end{array}$ \\
\hline 25 & Medicarpin & 48.6 & $\mathrm{C}_{16} \mathrm{H}_{14} \mathrm{O}_{4}$ & 269.0827 & $\begin{array}{c}\text { 254.0594; } 225.0540 ; \\
105.0191 ; 121.0300 \\
133.0287\end{array}$ \\
\hline 26 & Biochanin $A *$ & 52.0 & $\mathrm{C}_{16} \mathrm{H}_{12} \mathrm{O}_{5}$ & 283.0619 & $\begin{array}{c}\text { 268.0389; } 239.0354 ; \\
\text { 211.0393; } \\
132.0202 ; 195.4450\end{array}$ \\
\hline 27 & $\begin{array}{l}\text { 5,4'-Dihydroxy-7- } \\
\text { methoxyisoflavone }\end{array}$ & 53.1 & $\mathrm{C}_{16} \mathrm{H}_{12} \mathrm{O}_{5}$ & 283.0619 & $\begin{array}{l}\text { 268.0383; 211.0422; } \\
\text { 223.0402; 224.0506; }\end{array}$ \\
\hline 28 & $\begin{array}{c}3,9- \\
\text { Dimethoxypterocarpan }\end{array}$ & 63.0 & $\mathrm{C}_{17} \mathrm{H}_{16} \mathrm{O}_{4}$ & 283.0988 & $\begin{array}{c}253.0515 ; 225.0564 ; \\
268.0754 ; 183.0456 \\
254.0554\end{array}$ \\
\hline \multicolumn{6}{|c|}{ Flavonols } \\
\hline 29 & $\begin{array}{l}\text { 7-Hydroxy-6- } \\
\text { methoxydihydroflavonol }\end{array}$ & 30.9 & $\mathrm{C}_{16} \mathrm{H}_{14} \mathrm{O}_{5}$ & 285.0743 & $\begin{array}{l}\text { 270.0534; 268.0383; } \\
78.9984 ; 123.0078\end{array}$ \\
\hline \multicolumn{6}{|c|}{ Neoflavonoids } \\
\hline 30 & Dalbergin & 38.3 & $\mathrm{C}_{16} \mathrm{H}_{12} \mathrm{O}_{4}$ & 267.0667 & $\begin{array}{c}252.0465 ; 224.0503 ; \\
195.0451 ; 267.0650 ; \\
204.9615\end{array}$ \\
\hline
\end{tabular}


Table 3. Cont.

\begin{tabular}{|c|c|c|c|c|c|}
\hline Compound & $\begin{array}{c}\text { Putative Compound } \\
\text { Name }\end{array}$ & RT (min) & ProposedFormula & {$[\mathbf{M}-\mathbf{H}]-(m / z)$} & MS/MS Fragments $(\mathrm{m} / \mathrm{z})$ \\
\hline \multicolumn{6}{|c|}{ Polyprenylated benzophenones } \\
\hline 31 & $\begin{array}{c}\text { Guttiferone } \\
\text { E/Xanthochymol }\end{array}$ & 92.2 & $\mathrm{C}_{38} \mathrm{H}_{50} \mathrm{O}_{6}$ & 601.3567 & $\begin{array}{c}\text { 109.0291; } 108.0214 ; \\
\text { 202.9997; 177.0198; } \\
\text { 335.1285 }\end{array}$ \\
\hline 32 & Oblongifolin B & 93.8 & $\mathrm{C}_{38} \mathrm{H}_{50} \mathrm{O}_{6}$ & 601.3569 & $\begin{array}{l}\text { 109.0292; } 108.0216 \\
176.0146 ; 307.1362\end{array}$ \\
\hline
\end{tabular}

Bold values indicate the main fragments; $\mathrm{RT}=$ retention time; $[\mathrm{M}-\mathrm{H}]^{-}$(negative ionization mode) experimental mass of compound. * As compared to an authentic standard.

\subsubsection{Flavonoids}

Flavonoids are the main class of phenolic compounds in several natural products, including fruits, vegetables, roots, stems and flowers [32]. Multiple studies have revealed the beneficial effects of flavonoids extracted from propolis against human diseases [33]. In our study, a total of 28 flavonoids were identified in the BRP extract, which corresponded to the main chemical group present in the sample.

\subsubsection{Flavones}

Among the flavonoids detected in the BRP extract, six were flavones. Chrysin (compound 1 with $[\mathrm{M}-\mathrm{H}]^{-}$at $m / z 253.0510$ ) yielded a fragment at $m / z$ 253.0507 [34]. Tricin (compound 2 with $[\mathrm{M}-\mathrm{H}]^{-}$at $\mathrm{m} / z$ 329.0667) was tentatively identified based on product ions at $m / z 329.0667,299.0218[\mathrm{M}-\mathrm{H}-2 \mathrm{CH} 3]^{-}, 271.0263\left[\mathrm{M}-\mathrm{H}-\mathrm{C}_{2} \mathrm{H}_{2} \mathrm{O}_{2}\right]^{-}$, and 243.0289 $\left[\mathrm{M}-\mathrm{H}-\mathrm{C}_{4} \mathrm{H}_{6} \mathrm{O}_{2}\right]^{-}$. Genkwanin (compound 3 with $[\mathrm{M}-\mathrm{H}]^{-}$at $m / z 283.0624$ ) yielded the predominant $m / z 268$ fragment due to the loss of $\mathrm{CH}_{2}$ from the $\mathrm{m} / z 283$ fragment, resulting in a stable fragment structure [35]. Hispidulin (compound 4) was tentatively identified based on the $[\mathrm{M}-\mathrm{H}]^{-}$ion at $m / z$ 299.0565, with fragment ions at $m / z 284.0331\left[\mathrm{M}-\mathrm{CH}_{3}\right], 227.0354$ $\left[\mathrm{M}-\mathrm{CO}_{2}-\mathrm{CO}\right] ; 255.0301\left[\mathrm{M}-\mathrm{H}-\mathrm{CO}_{2}\right]$ and $212.0483\left[\mathrm{M}-\mathrm{H}-\mathrm{CO}_{2}-\mathrm{CO}-\mathrm{CH}_{3}\right]$ [34]. Compound 5 was tentatively characterized as 8-Hydroxy-5-methoxyflavanon $(m / z 269.0831)$ based on the $m / z 254.0589$ fragment. Finally, the characteristic $[\mathrm{M}-\mathrm{H}]^{-}$ion at $m / z 283.0617$ and a major fragmentation at $m / z 268.0382$ were suggestive of acacetin (compound 6) [36].

\subsubsection{Flavanones}

Retro-Diels-Alder (RDA) is the pathway fragmentation commonly used by flavanones. Fragment ions resulting from RDA fragments are more abundant than the loss of other radical ions, such as $\mathrm{CH}_{3}, \mathrm{CO}, \mathrm{OH}$, or $\mathrm{H}_{2} \mathrm{O}$ [37]. Liquiritigenin (compound 7) was detected with $[\mathrm{M}-\mathrm{H}]^{-}$at $m / z$ 255.0667. Its identity was confirmed by comparing with data from a previous study, in which Dalbergia odorifera was characterized by LC-MS/MS and based on the spectrum of product ions at $m / z 119.0495\left(\left[\mathrm{M}-\mathrm{H}-\mathrm{C}_{8} \mathrm{H}_{8} \mathrm{O}_{2}\right]^{-}\right)$and $m / z$ 135.0083, corresponding to breaks of $[1,3 \mathrm{~A}-\mathrm{H}]^{-}$and $[1,3 \mathrm{~B}-\mathrm{H}]^{-}$fragmen [38]. Four flavanones and derivates (compounds 8, 9, 10 and 11) were tentatively identified in the optimized BRP extract as naringenin, pinocembrin, 5,6-Dihydroxy-3 $3^{\prime}, 4^{\prime}$-dimethoxyflavanon and 6-Hydroxyflavanone, according to the precursor ions [M-H $]^{-}$at $m / z 271.0619,255.0668$, 315.0882 and 239.0722, respectively. The identification of naringenin was confirmed by a product ion at $m / z 119.0487$ [39]. Pinocembrin was identified by comparing our findings with those of a previous report, where this compound was found in leaf extracts of Alpinia zerumbe, yielding the $m / z 255.0678$ fragment [40]. Pinocembrin is an important marker in BRP, because it is also found in D. ecastaphyllum [9]. The compound 5,6-Dihydroxy-3', $4^{\prime}-$ dimethoxyflavanon (compound 10 with $[\mathrm{M}-\mathrm{H}]^{-}$at $m / z 315.0882$ ), which was found for the first time in BRP, was tentatively identified based on a product ion at $m / z$ 315.0881. Lastly, 6-Hydroxyflavanone displayed a product ion at $m / z 239.0732$ in the $\mathrm{MS}^{2}$ spectra [37]. 


\subsubsection{Chalcones}

Isoliquiritigenin (compound 12 with $[\mathrm{M}-\mathrm{H}]^{-}$at $m / z$ 255.0676) was previously described in the literature and tentatively identified herein based on product ions at $m / z 119.0496$ and 135.0082 [41]. The compound $2^{\prime}, 4^{\prime}$-Dihydroxychalcone (compound 13), detected with [M-H] ${ }^{-}$at $m / z$ 239.0723, was identified based on fragment ions at $m / z 239.0709,197.0609$ and 135.0085 [42] This compound was previously reported as an efficient antiviral targeting HlyU in Vibrio vulnificus [43]. Compound 14 was assigned as 7-hydroxyflavanone $(m / z 239.0719)$, yielding the $m / z 197.0610$ fragment [37]. Compound 15 was detected with [M-H] ${ }^{-}$at $m / z 271.0990$ and was tentatively identified as $2^{\prime}, 6^{\prime}$-dihydroxy-4'-methoxydihydrochalcone based on fragment ions at $m / z$ 254.0590, 135.0444 and 109.0287. Compound 16, with $[\mathrm{M}-\mathrm{H}]^{-}$at $m / z$ 271.0990, was identified as $2^{\prime}$-Hydroxy- $4^{\prime}$-methoxychalcone $\left(\mathrm{Cl}_{6} \mathrm{H1}_{3} \mathrm{O}_{3}{ }^{-}\right)$, yielding fragment ions at $\mathrm{m} / \mathrm{z} 237.0552,255.0665$ and 253.0872 . This compound was previously found in orange-yellow resin from Zuccagnia punctate [19].

\subsubsection{Isoflavonoids}

The isoflavones aglycones daidzein (compound 17, $m / z 253.0511$ ), formononetin (compound 22, $m / z$ 267.0666) and biochanin A (compound 25, $m / z 283.0619$ ) were detected in the BRP extract. Daidzein yielded a product ion at $m / z 253.0513\left[\mathrm{M}-\mathrm{C}_{6} \mathrm{H}_{10} \mathrm{O}_{5}\right]^{-}$as result of a loss of glucoside and another product ion at $m / z 135.0089$ [M- $\left.-\mathrm{H}_{-} \mathrm{C}_{8} \mathrm{H}_{6} \mathrm{O}\right]^{-}$[44]. The main fragment ions in the $\mathrm{MS}^{2}$ spectra of formononetin corresponded to successive losses of $\mathrm{CH}^{3}, \mathrm{CHO}$, and $\mathrm{CO}$ [39]. Its $\mathrm{MS}^{2}$ spectra showed fragment ions at $m / z 252.0431$ [M-H$\left.\mathrm{CH}_{3}\right]^{-}, 223.0404\left(\mathrm{C}_{14} \mathrm{H}_{7} \mathrm{O}_{3}\right)\left[\mathrm{M}-\mathrm{H}-\mathrm{CH}_{3}-\mathrm{CHO}\right]^{-}$and 195.0456 [M-H- $\left.\mathrm{CH}_{3}-\mathrm{CHO}-\mathrm{CO}\right]^{-}$. A fragment ion at $m / z 268.0389\left[\mathrm{M}-\mathrm{H}-\mathrm{CH}_{3}\right]^{-}$, which was produced due to the loss of a $\mathrm{CH}_{3}$ group, and ions at $m / z 239.0354\left[\mathrm{M}-\mathrm{CO}_{2}\right]$ and 211.0393 [M-CO $2-\mathrm{CO}$, were suggestive of Biochanin A fragmentation [34]. Compound 18, with [M-H] ${ }^{-}$at $m / z 283.0617$ $\left(\mathrm{C}_{16} \mathrm{H}_{11} \mathrm{O}_{5}\right)$, showed typical product ions at $m / z 268.0353\left(\mathrm{C}_{15} \mathrm{H}_{8} \mathrm{O}_{5}\right), 211.0422,224.0506$ and 239.0313. Therefore, it was tentatively classified as calycosin [45]. Dihydrobiochanin A (compound 19 with $[\mathrm{M}-\mathrm{H}]^{-}$at $m / z$ 285.0776) and vestitone (compound 20 with $[\mathrm{M}-\mathrm{H}]^{-}$at $m / z$ 285.0776) were characterized based on fragment ions at $m / z 270.0541$ and 270.0535, respectively [46,47]. Vestitol (compound 21), with [M-H] $]^{-}$at $m / z 285.0776\left(\mathrm{C}_{16} \mathrm{H}_{15} \mathrm{O}_{4}\right)$, displayed product ions at $m / z 135.0450\left(\mathrm{C}_{8} \mathrm{H}_{7} \mathrm{O}_{2}\right), 109.0282\left(\mathrm{C}_{6} \mathrm{H}_{5} \mathrm{O}_{2}\right)$ and 149.0604 [48]. Even though compound $22\left([\mathrm{M}-\mathrm{H}]^{-}\right.$at $m / z$ 271.0990) showed a similar fragment to vestitol, it was tentatively identified as neovestitol based on the main fragment ions at $m / z 135.0360$, 197.0482 and 212.0707 [5]. Vestitol and neovestitol have been previously isolated from $\mathrm{BRP}$ and were reported to have strong biological properties $[5,9]$. Compound $24\left([\mathrm{M}-\mathrm{H}]^{-}\right.$ at $m / z$ 255.0673) was tentatively identified as dimethyl medicarpin based on fragment ions at $m / z 255.0668,151.0032,107.0118$ and 213.0532. Compound 25 was characterized as medicarpin according to the precursor ion at $m / z 269.0827$. In its $\mathrm{MS}^{2}$ spectra, the following typical product ions were detected: $254.0594\left(\left[\mathrm{M}-\mathrm{H}-\mathrm{CH} 3^{\circ}\right]^{-}\right), 225.0540,105.0191,121.0300$ $\left(\mathrm{C}_{7} \mathrm{H}_{5} \mathrm{O}_{2},{ }^{3,5} \mathrm{~A}^{-}\right)$and 133.0287 [49]. Compound 27 (with [M-H] $]^{-}$at $m / z 283.0619$ ) and compound 28 (with [M-H] $]^{-}$at $m / z$ 283.0988) were tentatively identified as 5,1'-Dihydroxy7-methoxyisoflavone and 3,9-Dimethoxypterocarpan, respectively. In their MS² spectra, 5,1'-Dihydroxy-7-methoxyisoflavone displayed fragment ions at $m / z 268.0383$ [M-H- $\left.\mathrm{CH}_{3}\right]$, $211.0422\left[\mathrm{M}-\mathrm{CO}_{2}-\mathrm{CO}\right]$ and 223.0402 [M-H-CO- $\left.\mathrm{H}_{2} \mathrm{O}\right]$ [34].

3.4.6. Flavonols, Neoflavonoids, Coumarins, and Polyprenylated Benzophenone Derivates

Dalbergin (compound 30 with $[\mathrm{M}-\mathrm{H}]^{-}$at $m / z$ 267.0667) yielded product ions at $m / z 252.0465$ and 224.0503, corresponding to the loss of a $\mathrm{CO}_{2}$ and further loss of $\mathrm{H}_{2} \mathrm{O}$ from the precursor ion [47]. Compound 29 (with [M-H] ${ }^{-}$at $m / z$ 285.0743) was tentatively identified as 7-Hydroxy-6-methoxydihydroflavonol based on fragment ions at $m / z 270.0534$. Guttiferone E (Compound 31) displayed deprotonated molecular ion at $m / z$ 601.3571. Its $\mathrm{MS}^{2}$ spectra showed fragment ions at $m / z 109.0291\left[\mathrm{C}_{6} \mathrm{O}_{2} \mathrm{H}_{5}\right]^{-}, 108.0214,202.9997,177.0198$ [M-H- $\mathrm{C}_{10} \mathrm{H}_{16} \mathrm{O}^{-}, 335.1285$ [50]. Lastly, compound 32 (with [M-H] ${ }^{-}$at $m / z$ 601.3670) was tentatively identified as oblongifolin $\mathrm{B}$, yielding a fragment ion at $m / z 109.0292$. 
In addition to comparing the tentative compounds with the literature, we further compared the data against the electronic database available from metadata-centric approaches, such as the Mass Bank of North America (MoNA) and the Mass Bank. The LC-QTOFESI-MS/MS analysis in negative mode enabled the identification for the first time in BRP of the following phenolic compounds: Flavones (tricin, genkwanin, hispidulin and 8-Hydroxy-5-methoxyflavanone), flavanones (5,6-Dihydroxy-3' $4^{\prime}$-dimethoxyflavanone and 6-Hydroxyflavanone), chalcones ( $2^{\prime}, 4^{\prime}$-Dihydroxychalcone and $2^{\prime}, 6^{\prime}$-dihydroxy-4'methoxydihydrochalcone), isoflavonoids (dihydrobiochanin A, demethyl medicarpin, 5,4'-Dihydroxy-7-methoxyisoflavone and 3,9-Dimethoxypterocarpan) and flavanols (7-Hydroxy-6-methoxydihydroflavonol).

\section{Conclusions}

The optimization of conditions for extraction of antioxidant compounds from BRP extract was successfully performed using the Response Surface Methodology. The optimal extraction conditions for stronger antioxidant activity and higher phenolic content were $90 \%$ ethanol at $80^{\circ} \mathrm{C}$ for $30 \mathrm{~min}$. Under optimized conditions, BRP extract showed a TPC of $129.00 \mathrm{mg} \mathrm{GAE} / \mathrm{g}$. When examined for its antioxidant activity, the TEAC, FRAP and ORAC assays revealed that the optimized extract had $3471.76 \mu \mathrm{mol} \mathrm{TE} / \mathrm{g}, 1472.86 \mu \mathrm{mol}$ $\mathrm{Fe}^{2+} / \mathrm{g}$ and $4339.61 \mu \mathrm{mol} \mathrm{TE} /$ gof dry extract, respectively. Thirty-two phenolic compounds were tentatively identified by LC-QTOF-ESI-MS/MS, of which thirteen were found for the first time in BRP. Our study may guide further research in the field, since this is the first study that reported the optimization of the extraction of phenolic compounds from BRP samples. Collectively, our results highlight the importance of BRP as a source of a wide variety of phenolic compounds with significant antioxidant properties.

Supplementary Materials: The following are available online at https:/ /www.mdpi.com/2076-392 1/10/2/297/s1, Figure S1 Coefficient of desirability for optimization of TEAC and TPC in Brazilian red propolis extracts as a function of time $(\mathrm{min})$, temperature $\left({ }^{\circ} \mathrm{C}\right)$ and $\mathrm{EtOH}$ concentration $(\%)$.

Author Contributions: Conceptualization, D.V.d.M. and S.M.d.A.; methodology, D.V.d.M., A.P.d.S.S., A.P.M., and S.M.d.A.; software, D.V.d.M.; validation, D.V.d.M. and S.M.d.A.; formal analysis, D.V.d.M.; investigation, D.V.d.M.; resources, S.M.d.A. and A.P.M.; data curation, D.V.d.M. and S.M.d.A.; writing — original draft preparation, D.V.d.M. and S.M.d.A.; writing—review and editing, S.M.d.A., M.I., A.P.d.S.S., and P.L.R.; visualization, D.V.d.M. and S.M.d.A.; supervision, S.M.d.A.; project administration, S.M.d.A., M.I., and P.L.R.; funding acquisition, D.V.d.M. and S.M.d.A. All authors have read and agreed to the published version of the manuscript.

Funding: This research was supported by theCoordenação de Aperfeiçoamento de Pessoal de Nível Superior-CAPES (Finance Code 001), National Council for Scientific and Technological Development-CNPq (grant number 870493/1997-3) and The São Paulo Research FoundationFAPESP (grant number 19/11248-0).

Institutional Review Board Statement: Not applicable.

Informed Consent Statement: Not applicable.

Data Availability Statement: Data is contained within the article and Supplementary Materials.

Acknowledgments: The authors thank beekeepers from Maceió, $\mathrm{AL}$, Brazil, for providing the propolis samples.

Conflicts of Interest: The authors declare no conflict of interest.

\section{References}

1. Ghisalberti, E.L. Propolis: A Review. Bee World 1979, 60, 59-84. [CrossRef]

2. Silva, B.B.; Rosalen, P.L.; Cury, J.A.; Ikegaki, M.; Souza, V.C.; Esteves, A.; Alencar, S.M. Chemical composition and botanical origin of red propolis, a new type of Brazilian propolis. Evid. BasedComplement. Altern. Med. 2008, 5, 313-316. [CrossRef]

3. Freires, I.A.; De Alencar, S.M.; Rosalen, P.L. A pharmacological perspective on the use of Brazilian Red Propolis and its isolated compounds against human diseases. Eur. J. Med. Chem. 2016, 110, 267-279. [CrossRef] [PubMed] 
4. Franchin, M.; Freires, I.A.; Lazarini, J.G.; Nani, B.D.; da Cunha, M.G.; Colón, D.F.; de Alencar, S.M.; Rosalen, P.L. The use of Brazilian propolis for discovery and development of novel anti-inflammatory drugs. Eur. J. Med. Chem. 2018, 153, 49-55. [CrossRef]

5. Franchin, M.; Colón, D.F.; Da Cunha, M.G.; Castanheira, F.V.S.; Saraiva, A.L.L.; Bueno-Silva, B.; Alencar, S.M.; Cunha, T.M.; Rosalen, P.L. Neovestitol, an isoflavonoid isolated from Brazilian red propolis, reduces acute and chronic inflammation: Involvement of nitric oxide and IL-6. Sci. Rep. 2016, 6, 1-12. [CrossRef]

6. Alencar, S.M.; Cadorin, T.L.; Castro, M.L.; Ribeiro, I.S.; Costa Neto, C.M.; Cury, J.A.; Rosalen, P.L.; Ikegaki, M. Chemical composition and biological activity of a new type of Brazilian propolis: Red propolis. J. Ethnopharmacol. 2007, 113, 278-283. [CrossRef]

7. Piccinelli, A.L.; Lotti, C.; Campone, L.; Cuesta-Rubio, O.; Campo Fernandez, M.; Rastrelli, L. Cuban and Brazilian red propolis: Botanical origin and comparative analysis by high-performance liquid chromatography-photodiode array detection/electrospray ionization tandem mass spectrometry. J. Agric. Food Chem. 2011, 59, 6484-6491. [CrossRef] [PubMed]

8. Bueno-Silva, B.; Marsola, A.; Ikegaki, M.; Alencar, S.M.; Rosalen, P.L. The effect of seasons on Brazilian red propolis and its botanical source: Chemical composition and antibacterial activity. Nat. Prod. Res. 2017, 31, 1318-1324. [CrossRef]

9. Ccana-Ccapatinta, G.V.; Mejía, J.A.A.; Tanimoto, M.H.; Groppo, M.; de Carvalho, J.C.A.S.; Bastos, J.K. Dalbergia ecastaphyllum (L.) Taub. and Symphonia globulifera L.f.: The botanical sources of isoflavonoids and benzophenones in Brazilian red propolis. Molecules 2020, 25, 2060. [CrossRef] [PubMed]

10. Franchin, M.; Cólon, D.F.; Castanheira, F.V.S.; da Cunha, M.G.; Bueno-Silva, B.; Alencar, S.M.; Cunha, T.M.; Rosalen, P.L. Vestitol isolated from Brazilian red propolis inhibits neutrophils migration in the inflammatory process: Elucidation of the mechanism of action. J. Nat. Prod. 2016, 79, 954-960. [CrossRef]

11. Oldoni, T.L.C.; Cabral, I.S.R.; d'Arce, M.A.B.R.; Rosalen, P.L.; Ikegaki, M.; Nascimento, A.M.; Alencar, S.M. Isolation and analysis of bioactive isoflavonoids and chalcone from a new type of Brazilian propolis. Sep. Purif. Technol. 2011, 77, 208-213. [CrossRef]

12. Novak, E.M.; Silva, M.S.E.C.; Marcucci, M.C.; Sawaya, A.C.H.F.; Giménez-Cassina López, B.; Fortes, M.A.H.Z.; Giorgi, R.R.; Marumo, K.T.; Rodrigues, R.F.; Maria, D.A. Antitumoural activity of Brazilian red propolis fraction enriched with xanthochymol and formononetin: An in vitro and in vivo study. J. Funct. Foods 2014, 11, 91-102. [CrossRef]

13. Abd El-Salam, E.A.; Morsy, N.F.S. Optimization of the extraction of polyphenols and antioxidant activity from Malva parviflora L. leaves using Box-Behnken design. Prep. Biochem. Biotechnol. 2019, 49, 876-883. [CrossRef]

14. Riswanto, F.D.O.; Rohman, A.; Pramono, S.; Martono, S. Application of response surface methodology as mathematical and statistical tools in natural product research. J. Appl. Pharm. Sci. 2019, 9, 125-133. [CrossRef]

15. Jovanović, A.A.; Đorđević, V.B.; Zdunić, G.M.; Pljevljakušić, D.S.; Šavikin, K.P.; Gođevac, D.M.; Bugarski, B.M. Optimization of the extraction process of polyphenols from Thymus serpyllum L. herb using maceration, heat- and ultrasound-assisted techniques. Sep. Purif. Technol. 2017, 179, 369-380. [CrossRef]

16. Al-Duais, M.; Müller, L.; Böhm, V.; Jetschke, G. Antioxidant capacity and total phenolics of Cyphostemmadigitatum before and after processing: Use of different assays. Eur. Food Res. Technol. 2009, 228, 813-821. [CrossRef]

17. Melo, P.S.; Massarioli, A.P.; Denny, C.; Dos Santos, L.F.; Franchin, M.; Pereira, G.E.; Vieira, T.M.F.D.S.; Rosalen, P.L.; De Alencar, S.M. Winery by-products: Extraction optimization, phenolic composition and cytotoxic evaluation to act as a new source of scavenging of reactive oxygen species. Food Chem. 2015, 181, 160-169. [CrossRef]

18. Prakash Maran, J.; Manikandan, S.; Vigna Nivetha, C.; Dinesh, R. Ultrasound assisted extraction of bioactive compounds from Nephelium lappaceum L. fruit peel using central composite face centered response surface design. Arab. J. Chem. 2017, 10, S1145-S1157. [CrossRef]

19. Martín-García, B.; Pimentel-Moral, S.; Gómez-Caravaca, A.M.; Arráez-Román, D.; Segura-Carretero, A. A Box-Behnken design for optimal green extraction of compounds from olive leaves that potentially activate the AMPK pathway. Appl. Sci. 2020, 10, 4620. [CrossRef]

20. Gaur, P.K.; Shanmugam, S.K. Box-Behnken design-directed optimization of Wickerhamomycesanomalus-mediated biotransformation process to enhance the flavonoid profile of polyherbal extract. J. Pharm. Innov. 2020, 1-12. [CrossRef]

21. Roselló-Soto, E.; Martí-Quijal, F.J.; Cilla, A.; Munekata, P.E.S.; Lorenzo, J.M.; Remize, F.; Barba, F.J. Influence of temperature, solvent and $\mathrm{pH}$ on the selective extraction of phenolic compounds from tiger nuts by-products: Triple-TOF-LC-MS-MS characterization. Molecules 2019, 24, 797. [CrossRef] [PubMed]

22. Oldoni, T.L.C.; Oliveira, S.C.; Andolfatto, S.; Karling, M.; Calegari, M.A.; Sado, R.Y.; Maia, F.M.C.; Alencar, S.M.; Lima, V.A. Chemical characterization and optimization of the extraction process of bioactive compounds from propolis produced by selected bees Apis mellifera. J. Braz. Chem. Soc. 2015, 26, 2054-2062. [CrossRef]

23. Yang, L.; Jiang, J.G.; Li, W.F.; Chen, J.; Wang, D.Y.; Zhu, L. Optimum extraction process of polyphenols from the bark of Phyllanthus emblica L. based on the response surface methodology. J. Sep. Sci. 2009, 32, 1437-1444. [CrossRef]

24. Andrade, J.K.S.; Denadai, M.; de Oliveira, C.S.; Nunes, M.L.; Narain, N. Evaluation of bioactive compounds potential and antioxidant activity of brown, green and red propolis from Brazilian northeast region. Food Res. Int. 2017, 101, 129-138. [CrossRef] [PubMed]

25. Vuong, Q.V.; Golding, J.B.; Stathopoulos, C.E.; Nguyen, M.H.; Roach, P.D. Optimizing conditions for the extraction of catechins from green tea using hot water. J. Sep. Sci. 2011, 34, 3099-3106. [CrossRef] [PubMed] 
26. Yusof, N.; Munaim, M.S.A.; VelooKutty, R. Optimization of total phenolic compounds extracted from propolis by ultrasoundassisted extraction. Chem. Eng. Commun. 2020, 1-9. [CrossRef]

27. Calegari, M.A.; Ayres, B.B.; dos Santos Tonial, L.M.; de Alencar, S.M.; Oldoni, T.L.C. Fourier transform near infrared spectroscopy as a tool for predicting antioxidant activity of propolis. J. King Saud Univ. Sci. 2020, 32, 784-790. [CrossRef]

28. Svečnjak, L.; Marijanović, Z.; Okińczyc, P.; Kuś, P.M.; Jerković, I. Mediterranean propolis from the adriatic sea islands as a source of natural antioxidants: Comprehensive chemical biodiversity determined by GC-MS, ftiratr, UHPLC-DAD-QQTOF-MS, DPPH and FRAP assay. Antioxidants 2020, 9, 337. [CrossRef]

29. Lewoyehu, M.; Amare, M. Comparative evaluation of analytical methods for determining the antioxidant activities of honey: A review. Cogent Food Agric. 2019, 5, 5. [CrossRef]

30. El-Guendouz, S.; Aazza, S.; Lyoussi, B.; Bankova, V.; Popova, M.; Neto, L.; Faleiro, M.L.; Da Graça Miguel, M. Moroccan Propolis: A Natural Antioxidant, Antibacterial, and Antibiofilm against Staphylococcus aureus with no induction of resistance after continuous exposure. Evid. Based Complement. Altern. Med. 2018, 2018, 1-19. [CrossRef]

31. Sun, C.; Wu, Z.; Wang, Z.; Zhang, H. Effect of ethanol/water solvents on phenolic profiles and antioxidant properties of Beijing propolis extracts. Evid. Based Complement. Altern. Med. 2015, 2015, 1-9. [CrossRef] [PubMed]

32. Panche, A.N.; Diwan, A.D.; Chandra, S.R. Flavonoids: An overview. J. Nutr. Sci. 2016, 5, e47. [CrossRef] [PubMed]

33. Watanabe, M.A.E.; Amarante, M.K.; Conti, B.J.; Sforcin, J.M. Cytotoxic constituents of propolis inducing anticancer effects: A review. J. Pharm. Pharmacol. 2011, 63, 1378-1386. [CrossRef]

34. Peng, Q.; Shang, X.; Zhu, C.; Qin, S.; Zhou, Y.; Liao, Q.; Zhang, R.; Zhao, Z.; Zhang, L. Qualitative and quantitative evaluation of Oroxylum indicum (L.) Kurz by HPLC and LC-qTOF-MS/MS. Biomed. Chromatogr. 2019, 33, e4657. [CrossRef] [PubMed]

35. Yuan, L.; Liang, C.; Diao, X.; Cheng, X.; Liao, M.; Zhang, L. Metabolism studies on hydroxygenkwanin and genkwanin in human liver microsomes by UHPLC-Q-TOF-MS. Xenobiotica 2018, 48, 332-341. [CrossRef]

36. Hossain, M.B.; Rai, D.K.; Brunton, N.P.; Martin-Diana, A.B.; Barry-Ryan, A.C. Characterization of phenolic composition in lamiaceae spices by LC-ESI-MS/MS. J. Agric. Food Chem. 2010, 58, 10576-10581. [CrossRef]

37. Chen, Q.; He, L.; Mo, C.; Zhang, Z.; Long, H.; Gu, X.; Wei, Y. Rapid evaluation of chemical consistency of artificially induced and natural resinadraconis using Ultra-Performance Liquid Chromatography Quadrupole-Time-Of-Flight mass spectrometry-based chemical profiling. Molecules 2018, 23, 1850. [CrossRef]

38. Zhao, X.; Zhang, S.; Liu, D.; Yang, M.; Wei, J. Analysis of flavonoids in Dalbergia odorifera by ultra-performance liquid chromatography with tandem mass spectrometry. Molecules 2020, 25, 389. [CrossRef]

39. Rini Vijayan, K.P.; Raghu, A.V. Tentative characterization of phenolic compounds in three species of the genus Embelia by liquid chromatography coupled with mass spectrometry analysis. Spectrosc. Lett. 2019, 52, 653-670. [CrossRef]

40. Ghareeb, M.A.; Sobeh, M.; Rezq, S.; El-Shazly, A.M.; Mahmoud, M.F.; Wink, M. HPLC-ESI-MS/MS profiling of polyphenolics of a leaf extract from Alpinia zerumbet (Zingiberaceae) and its anti-inflammatory, anti-nociceptive, and antipyretic activities in vivo. Molecules 2018, 23, 3238. [CrossRef]

41. Wu, Y.; Wang, P.; Yang, H.; Sui, F. UPLC-Q-TOF-MS and UPLC-MS/MS methods for metabolism profiles and pharmacokinetics of major compounds in XuanmaiGanjie Granules. Biomed. Chromatogr. 2019, 33, 1-13. [CrossRef] [PubMed]

42. Agüero, M.B.; Gonzalez, M.; Lima, B.; Svetaz, L.; Sánchez, M.; Zacchino, S.; Feresin, G.E.; Schmeda-Hirschmann, G.; Palermo, J.; Daniel Wunderlin, A.N.D.; et al. Argentinean propolis from Zuccagnia punctata cav. (Caesalpinieae) exudates: Phytochemical characterization and antifungal activity. J. Agric. Food Chem. 2010, 58, 194-201. [CrossRef]

43. Imdad, S.; Batool, N.; Pradhan, S.; Chaurasia, A.K.; Kim, K.K. Identification of 2,4-dihydroxychalcone as an antivirulence agent targeting hlyu, a master virulence regulator in vibrio vulnificus. Molecules 2018, 23, 1492. [CrossRef] [PubMed]

44. Peng, H.; Li, W.; Li, H.; Deng, Z.; Zhang, B. Extractable and non-extractable bound phenolic compositions and their antioxidant properties in seed coat and cotyledon of black soybean (Glycine max (L.) merr). J. Funct. Foods 2017, 32, 296-312. [CrossRef]

45. Qi, Y.; Li, S.; Pi, Z.; Song, F.; Lin, N.; Liu, S.; Liu, Z. Chemical profiling of Wu-tou decoction by UPLC-Q-TOF-MS. Talanta 2014, 118, 21-29. [CrossRef]

46. Zhao, C.; Liu, Y.; Cong, D.; Zhang, H.; Yu, J.; Jiang, Y.; Cui, X.; Sun, J. Screening and determination for potential $\alpha$-glucosidase inhibitory constituents from Dalbergia odorifera T. Chen using ultrafiltration-LC/ESI-MSn. Biomed. Chromatogr. 2013, 27, 1621-1629. [CrossRef]

47. Zhong, B.; Robinson, N.A.; Warner, R.D.; Barrow, C.J.; Dunshea, F.R.; Suleria, H.A.R. LC-ESI-QTOF-MS/MS characterization of seaweed phenolics and their antioxidant potential. Mar. Drugs 2020, 18, 331. [CrossRef]

48. Omar, R.M.K.; Igoli, J.; Gray, A.I.; Ebiloma, G.U.; Clements, C.; Fearnley, J.; EdradaEbel, R.A.; Zhang, T.; De Koning, H.P.; Watson, D.G. Chemical characterisation of Nigerian red propolis and its biological activity against Trypanosoma brucei. Phytochem. Anal. 2016, 27, 107-115. [CrossRef]

49. Wang, H.Y.; Li, T.; Ji, R.; Xu, F.; Liu, G.X.; Li, Y.L.; Shang, M.Y.; Cai, S.Q. Metabolites of medicarpin and their distributions in rats. Molecules 2019, 24, 1966. [CrossRef] [PubMed]

50. de Souza, E.C.A.; da Silva, E.J.G.; Cordeirob, H.K.C.; Filhob, N.M.L.; da Felipe Silvac, M.A.; dos Reisd, D.L.S.; Portod, Carla Pilaud, E.J.; da Costaa, L.A.M.A.; De, A.D.L.S.; Menezese, C.F.A. Chemical compositions and antioxidant and antimicrobial activities of propolis Produced by Frieseomelittalongipes and Apis mellifera bees. Quim. Nova 2018, 41, 485-491. 